\title{
Peningkatan Aktivitas dan Hasil Belajar Biologi Sebagai Dampak Penerapan Model Pembelajaran Kooperatif Tipe Group Investigation
}

\author{
I Ketut Subudi ${ }^{*}$ \\ ${ }^{1}$ SMA Negeri 1 Kubutambahan, Buleleng, Bali, Indonesia
}

\section{A R T I C L E I N F O}

Article history:

Received 19 October 2020

Received in revised form

30 November 2020

Accepted 10 January 2021

Available online 10

February 2021

\section{Kata Kunci:}

Group Investigation

Aktivitas, Hasil Belajar

Keywords:

Group Investigation;

Activity, Learning

Outcomes

\begin{abstract}
A B S T R A K
Paradigma pembelajaran yang masih berpusat pada guru berdampak pada rendahnya keaktifan dan hasil belajar biologi siswa. Salah satu solusi untuk mengatasi masalah tersebut adalah dengan menerapkan model pembelajaran inovatif yang berpusat pada siswa. Penelitian ini bertujuan untuk meningkatkan aktivitas dan hasil belajar biologi melalui penerapan model pembelajaran kooperatif tipe Group Investigation (GI). Penelitian ini merupakan jenis penelian tindakan kelas (PTK) yang mengadaptasi model penelitian PTK dari Kemmis dan Taggart. Subjek dalam penelitian ini berjumlah 32 orang siswa. Data aktivitas belajar dikumpulkan dengan lembar observasi dan rubrik penilaian, sedangkan data hasil belajar dikumpulkan dengan menggunakan tes objektif. Data dalam penelitian ini dianalisis dengan statistik deskriptif. Hasil penelitian menunjukkan bahwa terjadi peningkatan aktivitas dan hasil belajar biologi siswa pada siklus II, skor klasikal rata-rata aktivitas belajar sebesar 14,8 dengan kategori aktif, dan skor klasikal rata-rata hasil belajar sebesar 81,7 dengan kategori baik. Sehingga dapat disimpulkan bahwa penerapan model Gl meningkatkan aktivitas dan hasil belajar biologi siswa.
\end{abstract}

A B S T R A C T

The teacher-centered learning paradigm has an impact on the low of students' activity and learning outcomes. One solution to overcoming this problem is by applying an innovative student-centered learning model. This study aims to increase the activities and biology learning outcomes through the application of the cooperative learning model with Group Investigation (GI). This study is a classroom action research (CAR) which adapts the CAR research model from Kemmis and Taggart. The subjects in this study were 32 students. Learning activity data were collected using the observation sheet and assessment rubric, while the learning outcome data were collected using objective tests. The data in this study were analyzed using descriptive statistics. The results showed that there was an increase in the students' activity and biology learning outcomes in cycle II, the classical average score of learning activities was 14.8 in the active category, and the classical average score of learning outcomes was 81.7 with good categories. So, it can be concluded that the application of the Gl model increases the students' activity and biology learning outcomes.

\section{Pendahuluan}

Proses pembelajaran mengakibatkan terjadinya suatu proses menguji strategi dan rencana yang memungkinkan timbulnya perbuatan belajar pada siswa (Tan et al., 2007; Wahyuningsih, 2017). Interaksi edukatif harus menggambarkan hubungan aktif dua arah dengan sejumlah pengetahuan sebagai mediumnya, sehingga interaksi itu merupakan hubungan yang bermakna dan kreatif. Semua unsur interaksi edukatif harus berproses dalam ikatan tujuan pendidikan. Karena itu, interaksi edukatif adalah suatu gambaran hubungan aktif dua arah antara guru dan anak didik yang berlangsung dalam ikatan 
tujuan pendidikan (Abdullah, 2011; Delismar et al., 2013). Guru harus melakukan banyak kegiatan dalam interaksi edukatif, diantaranya memahami prinsip-prinsip interaksi edukatif, menyiapkan bahan dan sumber belajar, memilih metode, alat dan alat bantu pengajaran, memilih pendekatan, dan mengadakan evaluasi setelah akhir kegiatan pengajaran (Lestari, 2017; Putri, 2018).

Pelajaran Biologi yang diajarkan pada tingkat sekolah menengah atas (SMA) bertujuan untuk membekali peserta didik pengetahuan, pemahaman, dan sejumlah kemampuan untuk memasuki jenjang pendidikan yang lebih tinggi serta mengembangkan ilmu dan teknologi (Agustanti, 2012; Daud, 2012). Untuk mencapai tujuan tersebut, maka diterapkan berbagai pendekatan, antara lain pendekatan induktif dalam bentuk proses inkuiri ilmiah pada tataran inkuiri terbuka (Hapsari et al., 2012; Natalia \& Yusuf, 2013). Proses inkuiri ilmiah bertujuan menumbuhkan kemampuan berpikir, bekerja dan bersikap ilmiah, serta berkomunikasi ilmiah sebagai salah satu aspek penting kecakapan hidup. Oleh karena itu, pembelajaran Biologi menekankan pada pemberian pengalaman belajar secara langsung melalui penggunaan dan pengembangan keterampilan proses dan sikap ilmiah (Daud, 2012; Hapsari et al., 2012). Dengan demikian, secara umum kompetensi bahan kajian ilmu Biologi meliputi dua aspek, yaitu aspek pemahaman konsep dan penerapannya serta aspek kerja ilmiah.

Pada kenyataannya di lapangan menunjukkan bahwa pembelajaran Biologi yang dilakukan oleh sebagian guru SMA lebih menekankan kepada hasil belajar dan mengabaikan proses, aspek pemahaman konsep, serta cendrung mengabaikan aspek kerja ilmiah. Pendekatan pembelajaran yang diimplementasikan di kelas kurang menampakkan prosedur dan struktur kegiatan yang menunjang pendekatan pembelajaran yang berorientasi pada siswa aktif dan dibuat aktif. Hal ini karena, pada proses pembelajaran tidak menunjukkan tahap-tahap yang memungkinkan siswa memperoleh, mengenal, memahami, dan mengaplikasikan konsep secara bermakna. Kondisi situasi belajar yang dikembangkan guru tidak memungkinkan siswa aktif mencari, mengolah dalam rangka mengkonstruksi pengetahuannya.

Adanya asumsi bahwa pengetahuan dapat dipindahkan secara utuh dari pikiran guru ke pikiran siswa tanpa memperhatikan konsepsi awal siswa yang miskonsepsi, menyebabkan guru merasa telah mengajar dengan baik namun siswanya tidak belajar (Hikmawati et al., 2020; Soleh et al., 2018). Ini berarti, bahwa pada diri siswa belum terjadi proses mengasimilasikan dan mengakomodasikan pengalaman-pengalaman atau bahan yang dipelajari dengan prakonsepsi yang sudah dimiliki (Fahmi \& Hidayati, 2017; Suryanda et al., 2016). Akibatnya, kemampuan berpikir, bekerja ilmiah, dan kemampuan memecahkan masalah yang dihadapi dalam kehidupan nyata sehari-hari di kalangan para siswa tidak berkembang sesuai dengan harapan (Nadiya et al, 2016).

Mata pelajaran biologi khususnya materi sistem respirasi pada manusia berkaitan dengan cara mempelajari permasalahan berdasarkan dengan fenomena kehidupan, baik secara kualitatif maupun kuantitatif (Ramdani, 2018). Belajar sistem respirasi pada hakekatnya adalah belajar mengenal diri pada siswa, sehingga pembelajaran biologi diharapkan bukan hanya untuk penguasaan kumpulan pengetahuan yang berupa fakta, konsep, dan prinsip saja tetapi juga merupakan suatu proses pemecahan masalah yang muncul dalam kehidupan sehari - hari, serta membentuk sikap peserta didik dalam kehidupan sehari-hari sehingga siswa akhirnya menyadari keindahan, keteraturan alam, dan meningkatkan keyakinan terhadap Tuhan Yang Maha Esa (Abdullah, 2011).

Berdasarkan hasil observasi yang dilakukan di SMA Negeri 1 Kubutambahan menunjukkan bahwa tingkat pencapaian hasil belajar siswa kelas XI IPA3 pada mata pelajaran biologi masih kurang. Hasil ulangan harian semester genap tahun pelajaran 2015/2016 pada materi sistem respirasi pada manusia, diperoleh hasil sebanyak 54,8 \% siswa mendapatkan nilai di bawah Kriteria Ketuntasan Minimal (KKM) yaitu 75, seperti ditunjukkan pada Tabel 1.

Tabel 1. Nilai Aspek Kognitif Pokok Bahasan Sistem Respirasi Kelas XI IPA3 Tahun Pelajaran 2015/2016 SMA Negeri 1 Kubutambahan

\begin{tabular}{llc}
\hline \multicolumn{1}{c}{ Aspek Kompetensi } & Keterangan \\
\hline \multirow{2}{*}{ Kognitif } & Daya serap & $71,15 \%$ \\
& Ketuntasan klasikal & $45,2 \%$ \\
\hline
\end{tabular}

Beberapa faktor yang diduga menyebabkan rendahnya standar pencapaian nilai biologi pada materi Sistem Respirasi adalah: (1) siswa belum mampu mendiskripsikan organ-organ respirasinya secara utuh (2) guru masih beracuan pada media gambar pada buku biologi sebagai sumber belajar, (3) guru juga tidak menghiraukan/peduli apakah siswanya telah atau belum memperoleh pengalaman belajar yang bermakna, (4) pada umumnya guru masih berpendapat bahwa mengajar itu suatu kegiatan menjelaskan dan menyampaikan informasi tentang konsep-konsep, tidak heran di kelas terlihat partisipasi siswa dalam pembelajaran begitu rendah, siswa tidak aktif berdiskusi; (5) model pembelajaran konvensional 
yang digunakan selama ini kurang memberikan kesempatan bagi siswa untuk dapat mengembangkan kemampuan berfikir kritis siswa, karena siswa cenderung hanya menerima materi dari guru, dan tidak mendapatkan kesempatan untuk belajar mandiri, sehingga mengakibatkan siswa cepat lupa terhadap materi yang telah disampaikan; (6) belum adanya inovasi dalam pembelajaran.

Solusi untuk memecahkan permasalahan dalam pembelajaran sistem respirasi adalah dengan menggunakan model dan media pembelajaran yang mampu memperkaya pengalaman belajar siswa (learning to do) dengan meningkatkan interaksi dengan lingkungannya, sehingga mampu membangun kemampuan berpikir kritis, pemahaman, dan pengetahuan siswa terhadap dunia di sekitarnya (learning to how dan learning to know) (Sherman, 1989). Model yang dimaksud adalah dengan menggunakan model pembelajaran kooperatif group investigation.

Group Investigationn (GI) merupakan salah satu bentuk model pembelajaran kooperatif yang menekankan pada partisipasi dan aktivitas siswa untuk mencari sendiri materi (informasi) pelajaran yang akan dipelajari melalui bahan-bahan yang tersedia, misalnya dari buku pelajaran atau siswa dapat mencari melalui internet (Fauzi et al., 2021). Siswa dilibatkan sejak perencanaan, baik dalam menentukan topik maupun cara untuk mempelajarinya melalui investigasi. Tipe ini menuntut para siswa untuk memiliki kemampuan yang baik dalam berkomunikasi maupun dalam keterampilan proses kelompok (Aini et al, 2018; Zayyin, 2017). Model Group Investigation dapat melatih siswa untuk menumbuhkan kemampuan berfikir mandiri. Keterlibatan siswa secara aktif dapat terlihat mulai dari tahap pertama sampai tahap akhir pembelajaran (Sharan \& Sharan, 2007; Supriatna, 2019). Untuk mendukung efektivitas pembelajaran kooperatif, maka dapat menggunakan berbagai media dan sumber belajar. Oleh karena itu guru dapat menggunakan berbagai sumber belajar, misalnya dengan membuat handout, lembar kerja siswa, ringkasan berita di surat kabar, majalah, radio, televisi, internet, dan dari lingkungan sekitar (Fauzi et al., 2021; Supriatna, 2019). Berdasarkan hal tersebut, maka melalui penerapan model pembelajaran kooperatif GI secara langsung melatih kemampuan scientifik siswa. Dengan belajar kelompok, memiliki potensi dapat meningkatkan aktivitas dan hasil belajar siswa dalam pembelajaran Biologi.

Aktivitas belajar merupakan rangkaian kegiatan secara sadar yang dilakukan seseorang sehingga mengakibatkan perubahan dalam dirinya yang berupa perubahan pengetahuan atau kemahiran yang sifatnya tergantung pada sedikit banyaknya perubahan (Artini et al., 2015). Semakin meningkat motivasi dan aktivitas belajar, yang ditunjukkan dari tingginya keterlibatan siswa dalam pembelajaran, diyakini meningkatkan kualitas proses dan hasil belajar (Zayyin, 2021). Meningkatkan motivasi dan aktivitas belajar siswa adalah keniscayaan dalam mewujudkan kegiatan pembelajaran berkualitas, karena peningkatan motivasi belajar berkontribusi langsung dan positif terhadap hasil belajar siswa.

Hasil belajar merupakan hasil yang diperoleh siswa setelah siswa tersebut melakukan proses belajar yang melibatkan aspek kognitif, afektif dan psikomotor yang diwujudkan dalam bentuk skor atau angka setelah mengikuti tes (Hikmawati et al., 2020; Nadiya et al., 2016). Hasil belajar merupakan bagian terpenting dalam pembelajaran. Hasil belajar siswa pada hakikatnya adalah perubahan tingkah laku sebagai hasil belajar dalam pengertian yang lebih luas mencakup bidang kognitif, afektif, dan psikomotorik (Delismar et al., 2013; Fahmi \& Hidayati, 2017). Beberapa penelitian yang relevan menunjukkan hasil positif penerapan model pembelajaran GI dalam pembelajaran. Pertama, menemukan bahwa pembelajaran kooperatif tipe Group Investigation (GI) mampu meningkatkan hasil belajar dan kemampuan berpikir kreatif dan kemampuan pemecahan masalah siswa. Lebih lanjut diurakan bahwa kemampuan berpikir kreatif dan pemecahan masalah berkorelasi positif terhadap hasil belajar siswa (Arnyana, 2004; Soleh, 2018). Kedua, hasil penelitian menemukan bahwa pembelajaran kooperatif tipe GI memiliki efektivitas dalam meningkatkan hasil belajar IPA siswa (Artini et al, 2018). Berdasarkan penelitian relevan tersebut, keterbaruan dari penelitian ini adalah menerapkan model pembelajaran kooperatif tipe GI sebagai upaya untuk meningkatkan aktivitas dan hasil belajar biologi siswa.

Penelitian ini bertujuan untuk meningkatkan aktivitas dan hasil belajar biologi melalui penerapan model pembelajaran kooperatif tipe Group Investigation (GI) pada siswa kelas XI IPA3 SMA Negeri 1 pada materi sistem respirasi pada manusia.

\section{Metode}

Penelitian ini merupakan Penelitian Tindakan Kelas (PTK) atau Classroom Action Research, yang secara umum merupakan jenis penelitian yang bertujuan untuk meningkatkan dan memperbaiki kualitas proses pembelajaran di sekolah pada umumnya dan di dalam kelas pada khususnya (Sugiyono, 2014). Penelitian Tindakan Kelas ini dilaksanakan di SMA Negeri 1 Kubutambahan, yang beralamat di Banjar Dinas Kaja Kauh, Desa Tamblang, Kecamatan Kubutambahan, Kabupaten Buleleng. Prosedur penelitian ini mengadaptasi model penelitian tindakan kelas menurut Kemmis dan Taggart, yaitu terdiri dari (1) tahap 
perencanaan (planing); (2) tahap tindakan (action); (3) tahap observasi/ evaluasi (evaluation); dan (4) tahap refleksi (reflection), kemudian kembali lagi ke tahap perencanaan, tahap tindakan dan seterusnya sehingga membentuk siklus (Aqib, 2006). Adapun prosedur penelitian tersebut disajikan pada Gambar 1.

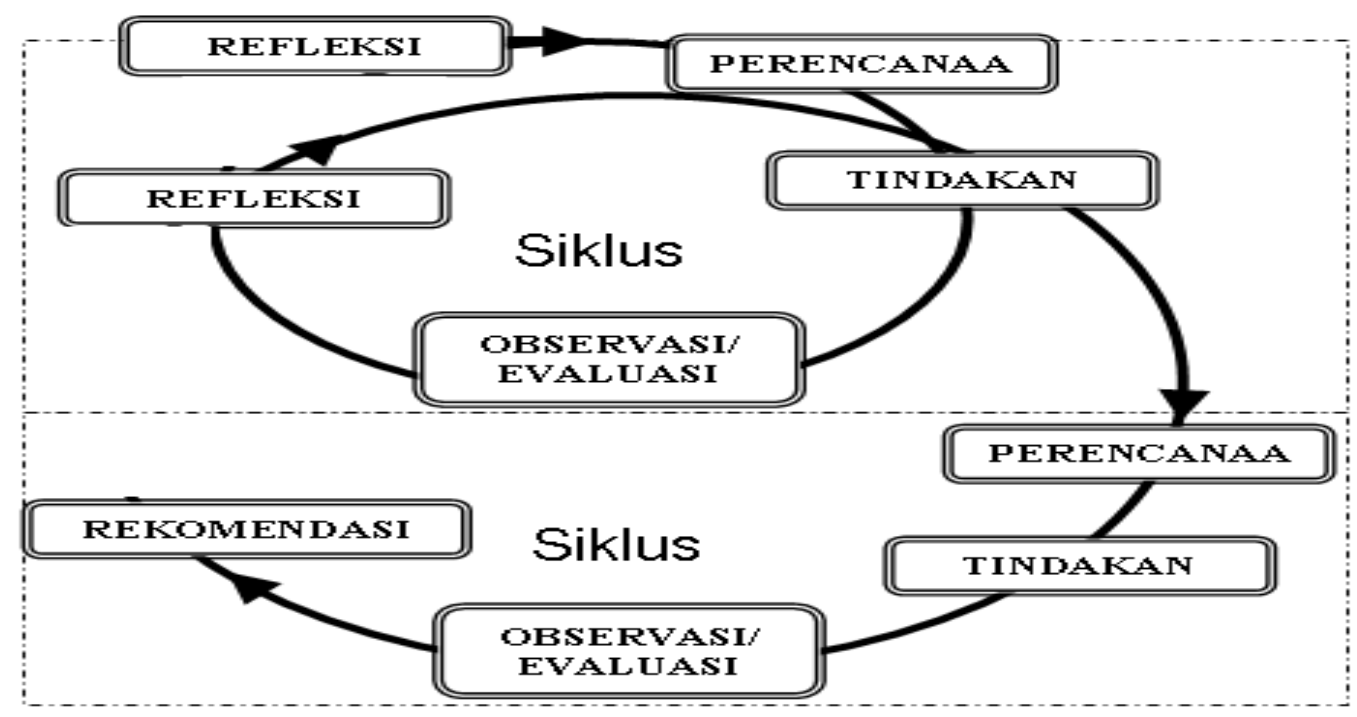

Gambar 1. Prosedur Penelitian Kemmis dan Taggart

Subjek dalam penelitian ini adalah seluruh siswa kelas XI IPA 3 pada semester genap tahun pelajaran 2016/2017. Kelas tersebut terdiri dari 32 siswa, dengan 15 orang siswa laki-laki dan 17 orang siswa perempuan. Objek dalam penelitian ini ialah aktivitas belajar dan hasil belajar siswa pada mata pelajaran Biologi, dengan materi sistem pernafasan/respirasi. Terdapat dua jenis data yang dikumpulkan dalam penelitian ini, yaitu data aktivitas belajar dan data hasil belajar biologi siswa. Data aktivitas belajar bersumber dari hasil pengamatan terhadap aktivitas belajar siswa selama proses pembelajaran, yang dinilai dengan menggunakan lembar observasi dan rubrik penilaian. Data hasil belajar biologi bersumber dari hasil evaluasi pada akhir siklus untuk materi sistem respirasi. Data ini dikumpulkan dengan menggunakan instrumen berupa tes objektif. Data aktivitas belajar yang diukur dengan menggunakan lembar observasi dan rubrik penilaian, memuat indikator dan deskriptor tentang aktivitas belajar. Lembar observasi yang digunakan terdiri dari 5 (lima) indikator yang masing-masing terdiri atas 4 (empat) deskriptor. Data yang diperoleh kemudian dianalisis secara deskriptif. Indikator ketercapaian aktivitas belajar dalam penelitian ini yaitu berada pada kategori minimal aktif. Data hasil belajar biologi siswa dianalisis dengan statistic diskriptif, yaitu dicari rata-ratanya, daya serap dan ketuntasan belajar, selanjutnya untuk mengetahui peningkatan yang terjadi, dapat dilihat dengan cara membandingkan hasil antar siklus. 2. Indikator keberhasilan hasil belajar siswa jika berada pada kategori baik, dengan skor rata-rata hasil belajar minimal 75 .

\section{Hasil dan Pembahasan}

\section{Deskripsi Data Pra-Siklus}

Data awal yang diperoleh sebelum dilaksanakannya penelitian tindakan kelas menunjukkan bahwa tingkat pencapaian hasil belajar siswa kelas XI IPA 3 pada mata pelajaran Biologi di SMA Negeri 1 Kubutambahan masih kurang. Hasil ulangan harian menunjukkan bahwa sebanyak 54.8\% siswa mendapatkan nilai di bawah Kriteria Ketuntasan Minimal (KKM), yaitu 75. Hasil ini mencerminkan bahwa pencapaian siswa masih sangat jauh dari harapan. Untuk mengatasi permasalahan tersebut, dilakukan perbaikan pembelajaran dengan menggunakan Model Pembelajaran Koopertif Tipe Group Investigation.

\section{Hasil Penelitian Pada Siklus I}

Hasil penelitian pada siklus I mencakup aktivitas belajar dan hasil belajar biologi siswa kelas XI IPA 3. Hasil analisis data disajikan pada Gambar 2 dan Gambar 3. 


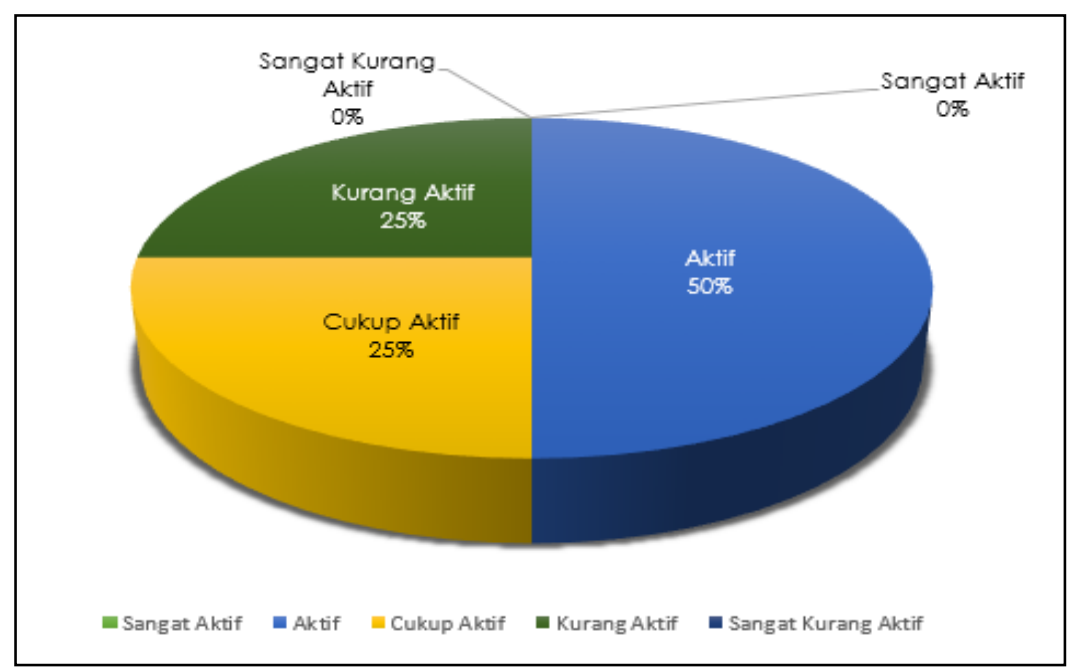

Gambar 2. Persentase Aktivitas Belajar Siswa Pada Siklus I

Berdasarkan data yang disajikan pada Gambar 2, persentase jumlah siswa yang memiliki aktivitas belajar termasuk kategori aktif sebesar $50 \%$, kategori cukup aktif $25 \%$, dan kategori kurang aktif $25 \%$ serta tidak ada siswa dengan kategori sangat aktif maupun sangat kurang aktif. Secara klasikal skor ratarata aktivitas belajar siswa sebesar 13,0 dengan kategori cukup aktif . Dari hasil tersebut tampak bahwa Penerapan Model Kooperatif Tipe Group Investigation belum dapat meningkatkan Aktivitas Belajar biologi siswa. Indikator keberhasilan peningkatan aktivitas belajar siswa yaitu apabila aktivitas belajar siswa berada pada kategori aktif.

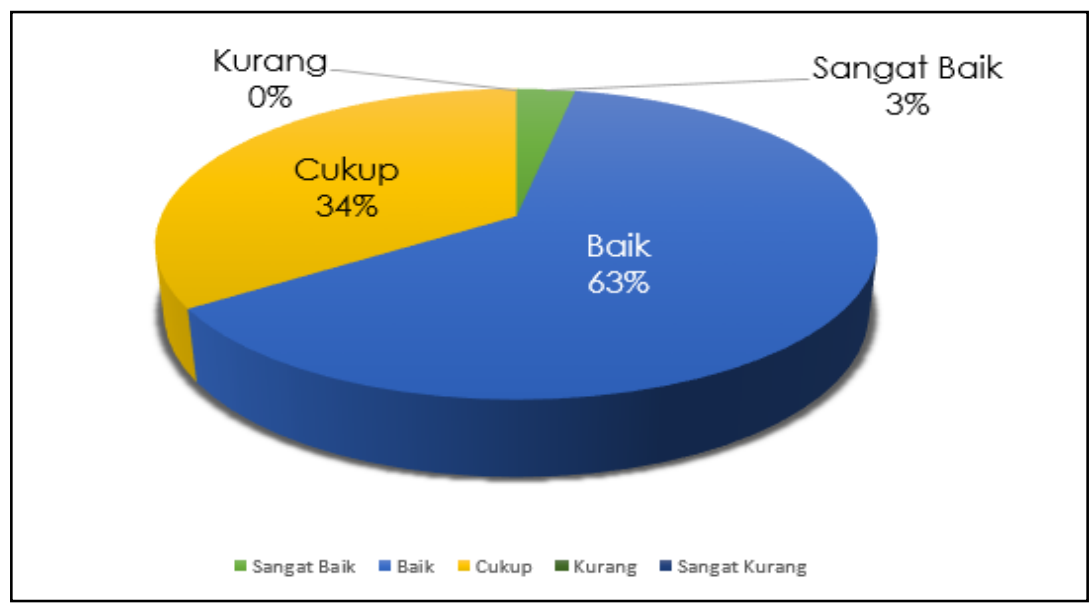

Gambar 3. Persentase Hasil Belajar Siswa Pada Siklus I

Berdasarkan data yang disajikan pada Gambar 3, persentase jumlah siswa yang memiliki prestasi belajar dengan kategori sangat baik, sebesar 3\%, kategori baik sebesar 63\%, kategori cukup 34\% dan tidak ada siswa dengan kategori kurang dan sangat kurang. Secara klasikal skor rata-rata hasil belajar biologi siswa sebesar 73,8 dengan kategori cukup. Data tersebut menunjukkan bahwa hasil belajar biologi siswa belum sesuai dengan harapan dalam penelitian ini. Indikator keberhasilan hasil belajar biologi siswa jika berada dalam kategori baik atau nilai rata-rata hasil belajar siswa di kelas sekurang-kurangnya 75.

\section{Hasil Penelitian Pada Siklus II}

Hasil penelitian pada siklus II mencakup aktivitas belajar dan hasil belajar biologi siswa kelas XI IPA 3. Hasil analisis data disajikan pada Gambar 4 dan Gambar 5. 


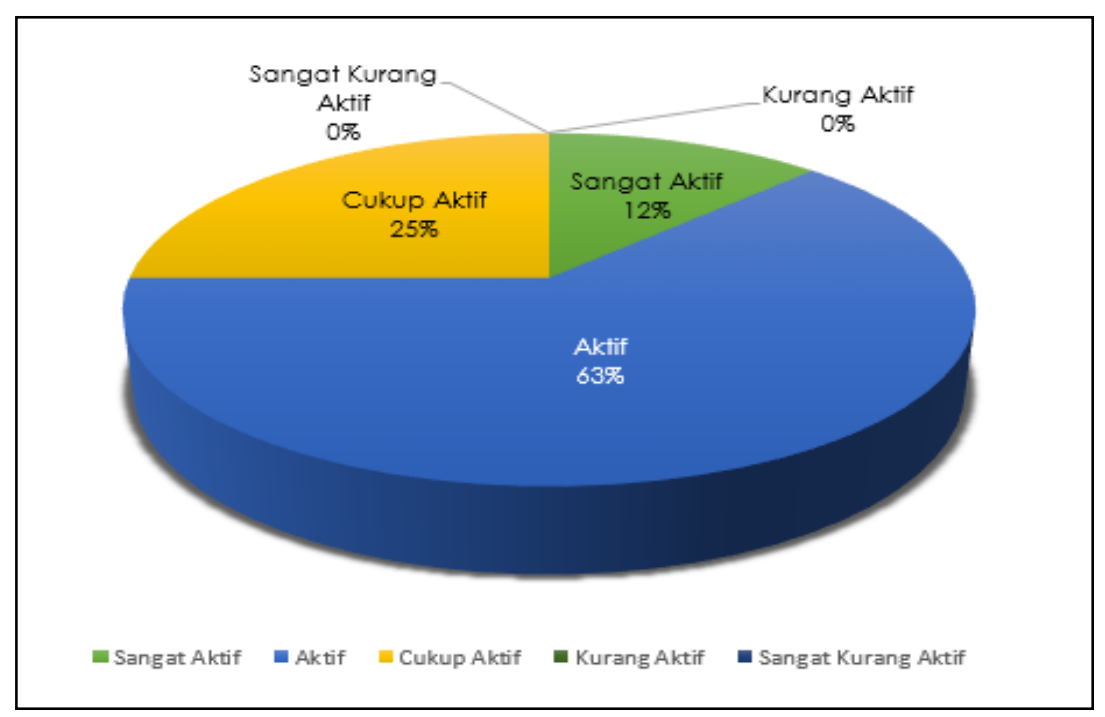

Gambar 4. Persentase Aktivitas Belajar Siswa Pada Siklus II

Berdasarkan data yang disajikan pada Gambar 4, persentase jumlah siswa yang memiliki aktivitas belajar termasuk kategori sangat aktif sebesar 12,5\%, kategori aktif sebesar 62,5\%, kategori cukup aktif $25 \%$, dan tidak ada siswa dengan kategori kurang aktif maupun sangat kurang aktif. Secara klasikal skor rata-rata aktivitas belajar siswa sebesar 14,8 dengan kategori aktif. Dari hasil tersebut tampak bahwa penerapan Model Kooperatif Tipe Group Investigation dapat meningkatkan aktivitas belajar biologi siswa. Indikator keberhasilan peningkatan aktivitas belajar siswa yaitu apabila aktivitas belajar siswa berada pada kategori aktif.

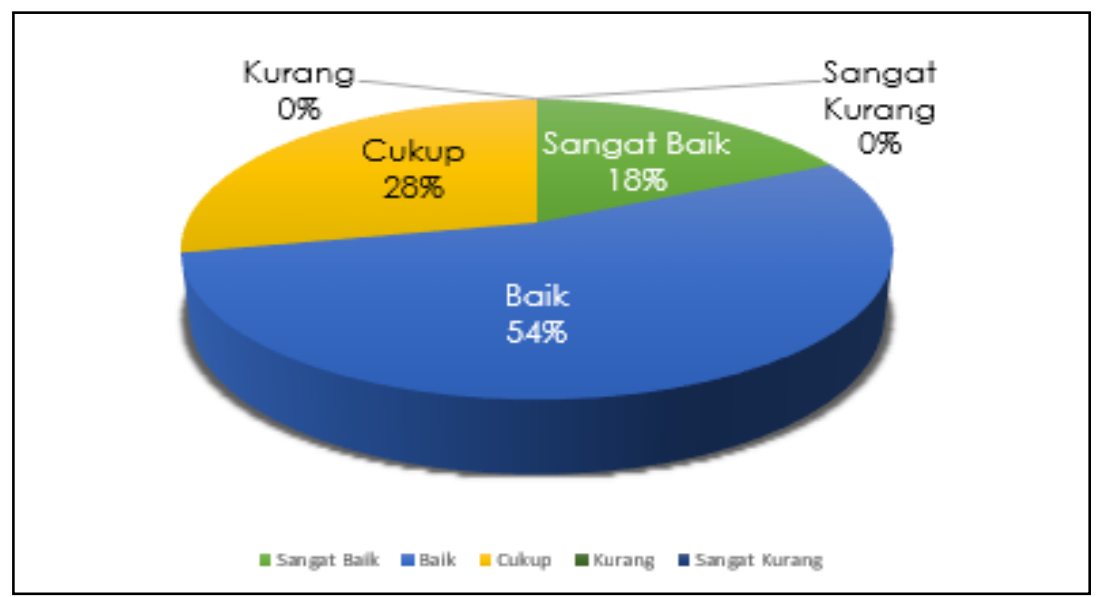

Gambar 5. Persentase Hasil Belajar Siswa Pada Siklus II

Berdasarkan data yang disajikan pada Gambar 5, persentase jumlah siswa yang memiliki Prestasi Belajar dengan kategori sangat baik, sebesar 18\%, kategori baik sebesar $54 \%$, kategori cukup $28 \%$, dan tidak ada siswa yang memperoleh kategori kurang dan sangat kurang. Secara klasikal skor rata-rata hasil belajar siswa sebesar 81,7 dengan kategori baik. Data tersebut menunjukkan bahwa hasil belajar siswa sudah sesuai dengan harapan dalam penelitian ini. Indikator keberhasilan hasil belajar siswa jika berada dalam kategori baik/ nilai rata-rata sekurang-kurangnya 75 .

\section{Pembahasan}

Berdasarkan pengamatan, banyaknya siswa yang memperoleh nilai hasil belajar yang cukup diakibatkan oleh beberapa faktor yaitu : 1) siswa belum terbiasa untuk mengubah pola belajar mereka yakni guru sebagai sumber informasi, 2) siswa masih terpaku pada obyek-obyek di luar materi pelajaran, sehingga waktu yang dibutuhkan lama, 3) siswa belum terbiasa mengidentifikasi konsep, sehingga konsep yang dihasilkan tidak relevan, 4) siswa kurang mempersiapkan diri di rumah dengan membaca terlebih 
dahulu materi pokok yang akan dibahas di sekolah. Ketidaksiapan siswa dalam mengikuti pembelajaran sangat besar pengaruhnya terhadap minat, motivasi, dan suasana kelas secara keseluruhan. Kondisi ini menunjukkan bahwa siswa hanya mempelajari materi pokok (bahan kajian), jika sudah pernah dibahas dalam pembelajaran di kelas. Dari hasil refleksi terhadap pembelajaran yang telah dilakukan, peneliti sebagai praktisi di kelas menemukan kelemahan dalam pembelajaran yaitu: 1) peneliti belum dapat mengontrol semua kelompok secara merata, mengingat hampir sebagian kelompok masih bertanya yang dikerjakan dalam LKS; 2) peneliti belum dapat memaksimalkan penguasaan konsep siswa; 3) peneliti belum dapat memaksimalkan waktu yang tersedia dalam pembelajaran.

Berdasarkan kendala tersebut, dilakukan beberapa perbaikan tindakan terhadap proses pembelajarannya, dengan melakukan kegiatan sebagai berikut: (1) sebelum pelaksanaan tindakan siklus II, guru/peneliti menekankan kembali mengenai pembelajaran, baik langkah pembelajaran, maupun aspek-aspek yang terkait dengan penilaian sehingga siswa lebih aktif dan kreatif dalam proses pembelajarannya; (2) guru menekankan konsep pembelajaran; (3) guru memberikan penekanan tentang LKS yang akan dikerjakan siswa.

Setelah diadakan perbaikan pada siklus II, perolehan nilai aktivitas belajar dan prestasi belajar biologi siswa mengalami peningkatan. Skor rata-rata aktivitas belajar siswa 14,8 dengan kategori aktif dan hasil belajar siswa sebesar 81,7 dengan kategori baik, daya serap sebesar $81,7 \%$ dan ketuntasan klasikalnya 87,5 \%. Dari kategori yang ditetapkan maka penelitian ini sudah mencapai kategori keberhasilan, yakni: indikator keberhasilan peningkatan aktivitas belajar siswa jika berada dalam kategori aktif dan prestasi belajar siswa jika berada pada kategori baik, dengan skor rata-rata hasil belajar kelas minimal 75.

Group Investigationn (GI) merupakan salah satu bentuk model pembelajaran kooperatif yang menekankan pada partisipasi dan aktivitas siswa untuk mencari sendiri materi (informasi) pelajaran yang akan dipelajari melalui bahan-bahan yang tersedia, misalnya dari buku pelajaran atau siswa dapat mencari melalui internet (Fauzi et al., 2021). Siswa dilibatkan sejak perencanaan, baik dalam menentukan topik maupun cara untuk mempelajarinya melalui investigasi. Tipe ini menuntut para siswa untuk memiliki kemampuan yang baik dalam berkomunikasi maupun dalam keterampilan proses kelompok (Aini et al, 2018; Zayyin, 2017). Model Group Investigation dapat melatih siswa untuk menumbuhkan kemampuan berfikir mandiri. Keterlibatan siswa secara aktif dapat terlihat mulai dari tahap pertama sampai tahap akhir pembelajaran (Sharan \& Sharan, 2007; Supriatna, 2019). Untuk mendukung efektivitas pembelajaran kooperatif, maka dapat menggunakan berbagai media dan sumber belajar. Oleh karena itu guru dapat menggunakan berbagai sumber belajar, misalnya dengan membuat handout, lembar kerja siswa, ringkasan berita di surat kabar, majalah, radio, televisi, internet, dan dari lingkungan sekitar (Fauzi et al., 2021; Supriatna, 2019). Berdasarkan hal tersebut, maka melalui penerapan model pembelajaran kooperatif GI secara langsung melatih kemampuan scientifik siswa. Dengan belajar kelompok, memiliki potensi dapat meningkatkan aktivitas dan hasil belajar siswa dalam pembelajaran Biologi.

Beberapa manfaat yang dapat diambil dari penelitian ini yaitu : (1) Penerapan Model Kooperatif Group Investigation dapat memberikan pengalaman baru dan menyenangkan baik bagi guru maupun siswa; (2) siswa dapat melakukan pengulangan dalam pembelajaran sehingga meningkatkan pemahaman siswa terhadap sains dan akan lebih tertarik terhadap sains; (3) siswa dapat mengejar ketertinggalan pengetahuan tentang Iptek di bidang pendidikan; (4) dapat meningkatkan motivasi belajar para pembelajar sehingga peserta didik tidak merasa bosan dan terjadi proses pembelajaran yang menyenangkan; dan (5) dapat digunakan untuk membantu membentuk model mental yang akan memudahkan pembelajar memahami suatu konsep.

\section{Simpulan dan Saran}

Berdasarkan hasil analisis dan pembahasan tentang Penerapan Model Pembelajaran Kooperatif Tipe Group Investigation, dapat disimpulkan bahwa penerapan Model Pembelajaran Kooperatif Tipe Group Investigation dapat meningkatkan aktivitas belajar siswa dalam pembelajaran Biologi Siswa Kelas XI IPA 3 SMA Negeri 1 Kubutambahan pada Semester Genap Tahun Pelajaran 2016/2017. Selain itu, penerapan Model Pembelajaran Kooperatif Tipe Group Investigation juga meningkatkan hasil belajar siswa dalam pembelajaran Biologi Siswa Kelas XI IPA 3 SMA Negeri 1 Kubutambahan pada Semester Genap Tahun Pelajaran 2016/2017. Sejalan dengan hasil penelitian tersebut, disarankan agar guru-guru dapat menerapkan dan mengembangkan Model Pembelajaran Kooperatif Tipe Group Investigation sesuai dengan situasi dan kondisi di sekolah. Selain itu, guru hendaknya terus melakukan inovasi model pembelajaran sehingga dapat meningkatkan kualitas proses dan hasil belajar. 


\section{Daftar Rujukan}

Abdullah, A., Oviana, W., \& Khatimah, H. (2011). Penggunaan Alat Peraga dari Bahan Bekas dalam Menjelaskan Sistem Respirasi Manusia di MAN Sawang Kabupaten Aceh Selatan. Jurnal Biologi Edukasi, 3(2), 51-55. http://202.4.186.66/JBE/article/view/469.

Agustanti, T. H. (2012). Implementasi metode inquiry untuk meningkatkan hasil belajar biologi. Jurnal Pendidikan IPA Indonesia, 1(1). https://doi.org/10.15294/jpii.v1i1.2007.

Aini, Z., Ramdani, A., \& Raksun, A. (2018). Perbedaan penguasaan konsep biologi dan kemampuan berpikir kritis siswa kelas X pada penerapan model pembelajaran kooperatif tipe group investigation dan guided inquiry di MAN 1 Praya. Jurnal Pijar Mipa, 13(1), 19-23. http://dx.doi.org/10.29303/jpm.v13i1.466.

Aqib, Z. (2006). Penelitian Tindakan Kelas. Yrama Widya.

Arnyana, I. B.P. (2007). Pengaruh Penerapan Model PBL dipandu Strategi Kooperatif Terhadap kecakapan Berpikir Kritis Siswa SMA Pada Mata Pelajaran Biologi. Jurnal Pendidikan dan Pengajaran, 38 (4), 646-667.

Artini, A., Pasaribu, M., \& Husain, S. M. (2015). Penerapan Model Pembelajaran Kooperatif Tipe Group Investigation Untuk Meningkatkan Aktivitas Dan Hasil Belajar IPA Pada Siswa Kelas VI SD Inpres 1 Tondo. Mitra Sains, $3(1), \quad$ 45-52. http://jurnal.pasca.untad.ac.id/index.php/MitraSains/article/view/53.

Daud, F. (2012). Pengaruh kecerdasan emosional (EQ) dan motivasi belajar terhadap hasil belajar Biologi siswa SMA 3 Negeri Kota Palopo. Jurnal Pendidikan dan Pembelajaran (JPP), 19(2), 243-255. http://journal.um.ac.id/index.php/pendidikan-dan-pembelajaran/article/view/3475.

Delismar, D., Asyhar, R., \& Hariyadi, B. (2013). Peningkatan kreativitas dan keterampilan proses sains siswa melalui penerapan model Group Investigation. Edu-Sains: Jurnal Pendidikan Matematika dan Ilmu Pengetahuan Alam, 2(1). https://doi.org/10.22437/jmpmipa.v2i1.1352.

Fahmi, D., \& Hidayati, H. (2017). Pengaruh Pembelajaran Tipe Group Investigation Terhadap Prestasi Belajar Fisika. COMPTON: Jurnal Ilmiah Pendidikan Fisika, 3(1). http://dx.doi.org/10.30738/cjipf.v3i1.668.g1019.

Fauzi, F., Erna, M., \& Linda, R. (2021). The Effectiveness of Collaborative Learning Throughtechniques on Group Investigation and Think Pair Share Students' Critical Thinking Ability on Chemical Equilibrium Material. Journal of Educational Sciences, 5(1), 198-208. http://dx.doi.org/10.31258/jes.5.1.p.198-208.

Hapsari, D. P., Sudarisman, S., \& Marjono, M. (2012). Pengaruh Model Inkuiri Terbimbing Dengan Diagram V (Vee) dalam Pembelajaran Biologi Terhadap Kemampuan Berpikir Kritis Dan Hasil Belajar Siswa. Pendidikan Biologi, 4(3). https://jurnal.fkip.uns.ac.id/index.php/bio/article/view/1423.

Hikmawati, H., Munir, A., \& Parakkasi, P. (2020). Implementation of Group Investigation (GI) Cooperative Learning Model to Improve Students' Critical Thinking Skills in Biology Subject. Journal of $\begin{array}{llll}\text { Biological Science } & \text { and } & \text { 6ducation, } & \text { 2(2), }\end{array}$ https://usnsj.com/index.php/biology/article/view/2.2.69-78.

Lestari, S. (2017). Penerapan Pembelajaran Group Investigation Untuk Meningkatkan Prestasi dan Keaktifan Siswa Materi Statistika. Journal of Medives: Journal of Mathematics Education IKIP Veteran Semarang, $\quad 1(2), \quad 150-157 . \quad$ http://ejournal.ivet.ac.id/index.php/matematika/article/view/491.

Nadiya, N., Rosdianto, H., \& Murdani, E. (2016). Penerapan Model Pembelajaran Group Investigation (GI) untuk Meningkatkan Keterampilan Berpikir Kritis Siswa pada Materi Gerak Lurus Kelas X. JIPF (Jurnal Ilmu Pendidikan Fisika), 1(2), 49-51. https://dx.doi.org/10.26737/jipf.v1i2.63.

Natalina, M., \& Yusuf, Y. (2013). Penerapan Strategi Pembelajaran Inkuiri Terbimbing untuk Meningkatkan Sikap Ilmiah dan Hasil Belajar Biologi Siswa Kelas VIII7 SMP Negeri 14 Pekanbaru $\begin{array}{lllll}\text { Tahun Ajaran } & \text { 2012/2013. Biogenesis, } & \text { 9(2), }\end{array}$ https://biogenesis.ejournal.unri.ac.id/index.php/JPSB/article/view/1896. 
Putri, D. (2018). Improving News Writing Skill by Using Cooperative Type Group Investigation Strategy. Curricula: Journal of Teaching and Learning, 3(2), 76-86. http://ejournal.lldikti10.id/index.php/curricula/article/view/2878.

Ramdani, D., \& Badriah, L. (2018). Korelasi Antara Kemampuan Berpikir Kritis Dengan Hasil Belajar Siswa Melalui Model Pembelajaran Inkuiri Terbimbing Berbasis Blended Learning Pada Materi Sistem Respirasi Manusia. BIO EDUCATIO:(The Journal of Science and Biology Education), 3(2). http://dx.doi.org/10.31949/be.v3i2.1117.

Sharan, Y., \& Sharan, S. (1992). Expanding cooperative learning through group investigation (Vol. 1234). Teachers College Press.

Sherman, L. W. (1989). A comparative study of cooperative and competitive achievement in two secondary biology classrooms: The group investigation model versus an individually competitive goal structure. Journal of research in science teaching, 26(1), 55-64. https://doi.org/10.1002/tea.3660260106.

Soleh, U., Ferdianto, F., \& Setiyani, S. (2018). Korelasi Model Group Investigation Dengan Kemampuan Berpikir Kreatif Dan Kemampuan Pemecahan Masalah. Kalamatika: Jurnal Pendidikan Matematika, 3(2), 139-154. https://doi.org/10.22236/KALAMATIKA.vol3no2.2018pp139-154.

Sugiyono. (2014). Metode Penelitian Pendidikan Pendekatan Kuantitatif, Kualitatif, dan R\&D. Alfabeta.

Supriatna, A. (2019). Penerapan Model Pembelajaran Kooperatif Tipe Group Investigation Untuk Meningkatkan Hasil Belajar Dasar dan Pengukuran Listrik Siswa Kelas X Titl-1 SMK Negeri 3 Kuningan. Syntax Literate; Jurnal Ilmiah Indonesia, 4(12), 36-46. http://dx.doi.org/10.36418/syntax-literate.v4i12.826.

Suryanda, A., Azrai, E. P., \& Wari, N. (2016). Pengaruh penerapan model pembelajaran Group Investigation (GI) terhadap kemampuan berpikir analisis siswa pada materi pencemaran lingkungan. Biosfer: Jurnal Pendidikan Biologi, 9(2), 37-44. https://doi.org/10.21009/biosferjpb.9-2.6.

Tan, I. G. C., Sharan, S., \& Lee, C. K. E. (2007). Group investigation effects on achievement, motivation, and perceptions of students in Singapore. The Journal of Educational Research, 100(3), 142-154. https://doi.org/10.3200/JOER.100.3.142-154.

Wahyuningsih, I. (2017). Pengaruh Model Pembelajaran Kooperatif Tipe Group Investigation Terhadap Hasil Belajar IPA. Natural: Jurnal Ilmiah Pendidikan IPA, 4(1), 26-33. https://jurnal.ustjogja.ac.id/index.php/NATURAL/article/view/1861.

Zayyin, A. (2017). Meningkatkan Keaktifan dan Hasil Belajar Matematika dengan Model Pembelajaran Kooperatif Tipe Group Investigation. UNION: Jurnal Ilmiah Pendidikan Matematika, 5(1), 11-20. https://jurnal.ustjogja.ac.id/index.php/union/article/view/935. 